\title{
"Então, eu fui à luta!": repensando as representações e práticas econômicas de grupos populares a partir de uma trajetória de ascensão social
}

\author{
Lúcia Helena Alves Müller*
}

\section{Resumo}

Esse texto traz indagações que surgiram no desenvolvimento de uma pesquisa que tem como temática o processo, em pleno curso no Brasil atual, de incremento do acesso de grupos populares a serviços e mecanismos financeiros, e de crescimento da oferta de crédito aos indivíduos de baixa renda. Tendo como fio condutor a trajetória de uma informante, desenvolveremos o questionamento de alguns dos pressupostos iniciais da pesquisa e tentaremos construir novas hipóteses de trabalho que buscam relativizar as diferenças e nuançar as fronteiras inicialmente presumidas entre as lógicas que orientariam a vida econômico-financeira dos indivíduos pertencentes às camadas populares e os princípios que regeriam os procedimentos dos agentes que lhes prestam serviços financeiros.

Palavras-chave: Antropologia Econômica, Sociologia Econômica, crédito e consumo, classes populares e práticas econômicas, mobilidade social.

\section{Introdução}

- sse texto traz indagações que foram colocadas ao longo do Edesenvolvimento de uma pesquisa cujo tema é o processo, em pleno curso no Brasil atual, de incremento do acesso a serviços e mecanismos financeiros por parte de grupos populares, e de crescimento da oferta de crédito aos indivíduos de baixa renda (KUMAR, 2004; MATOSO, 2005). O objetivo da pesquisa é o de compreender

Doutora em Antropologia Social pela Universidade de Brasília (UnB). Professora de Pós-Graduação em Ciências Sociais da Pontifícia Universidade Católica do Rio Grande do Sul. Endereço eletrônico: lucia.helena@pucrs.br. 
como os grupos sociais que estão sendo incorporados ao mercado de serviços financeiros (como resultado do incentivo das políticas públicas ou através da ação das instituições financeiras que concorrem no mercado) vivenciam esse processo, e como esses recursos e instrumentos financeiros são incorporados ao seu universo simbólico e a suas práticas cotidianas. ${ }^{1}$

A problemática embutida na formulação desse objetivo estava ligada à idéia, dominante em nosso senso comum, de que as instituições financeiras, assim como os seus usuários e clientes tradicionais (profissionais, grupos dominantes) teriam suas práticas orientadas por uma ideologia de caráter individualista, que eles orientariam suas ações pela lógica da maximização, baseando-se fundamentalmente no cálculo formal e abstrato.

A proposta seria, portanto, a de investigar como os indivíduos pertencentes às camadas populares compreendem e incorporam as ferramentas, os serviços e produtos financeiros que lhes estão sendo oferecidos, na medida em que, de acordo com diversos autores (VELHO, 1994; JARDIM (1998); SARTI (2003); FONSECA (2000, 2006); DUARTE (2008), entre outros), nos grupos populares urbanos, as famílias constituem uma rede de relações e obrigações mútuas que se mantém fundamental para a sobrevivência material e na definição dos parâmetros simbólico da inserção social dos indivíduos. Esses indivíduos estariam, assim, mergulhados em uma ideologia de caráter predominantemente holista, submetidos a padrões de comportamento e de obrigações familiares, nos quais há uma forte demarcação de papéis sociais de gênero e de geração que impossibilitam ou dificultam a formulação de um projeto individual.

Além dessas hipóteses de trabalho, com as quais guiamos o trabalho de pesquisa, também buscávamos avaliar outras idéias que costumam estar implícitas nas dicotomias dominantes no senso comum. Uma delas é a de que a precariedade material faz com que as práticas populares sejam predominantemente pautadas pelo imediatismo e pelo cálculo prático. Outra seria a de que o predo-

1 Esse texto é resultado de uma pesquisa que contou com financiamento do CNPq. Participou de sua realização a bolsista de Iniciação Científica da Fapergs, Eleonora França Teixeira. 
"Então, eu fui à luta!": repensando as representações e práticas econômicas de grupos populares a partir de uma trajetória de ascensão social

mínio do pensamento mágico/religioso inibiria o espaço de ações baseadas na racionalidade formal.

Tendo por fio condutor a trajetória de uma informante, desenvolveremos o questionamento de alguns dos pressupostos iniciais dessa pesquisa e tentaremos construir novas hipóteses de trabalho que buscam relativizar as diferenças e nuançar as fronteiras inicialmente presumidas entre as lógicas que orientariam a vida econômico-financeira dos indivíduos pertencentes às camadas populares e os princípios que regeriam os procedimentos dos agentes que lhes prestam serviços financeiros.

\section{Instituições financeiras e suas lógicas}

As lógicas que ordenam as práticas no âmbito de instituições financeiras já foram alvo de análise em outros trabalhos, como o que resultou de uma etnografia realizada junta a Bolsa de Valores de São Paulo (MÜLLER, 2007). Através desse estudo buscou-se demonstrar que, mesmo no interior de uma instituição central ao sistema econômico capitalista, cujas regras de funcionamento baseiam-se no modelo teórico do mercado perfeito, as relações entre os participantes são pautadas por lógicas muito variadas (investimento na esfera produtiva, especulação, aposta). Embora detenham graus variados de legitimidade social e seus protagonistas sejam alvo de avaliações morais muito diversas, essas práticas e as lógicas a elas subjacentes fazem parte do funcionamento normal daquela instituição.

A etnografia sobre o mercado acionário também levou-nos a perceber que, embora as trocas realizadas na bolsa sejam organizadas a partir do princípio da chamada "livre concorrência", isto é, através confronto impessoal e efêmero entre as ofertas de compra e de venda que são anunciadas no pregão (seja ele a viva voz ou eletrônico), o que direciona a ação dos participantes do mercado são as interpretações que eles fazem das informações consideradas relevantes para a avaliação das ações. A precedência no acesso e a confiabilidade das informações são os principais alvos perseguidos pelos participantes do mercado, através de um esforço permanente para estabelecerem e manterem relações de confiança com outros 
participantes. Relações que podem ser formais e de caráter duradouro (vínculos de trabalho, de prestação de serviço, contratos e parceria nos negócios), mas também informais, baseadas em redes de troca recíproca que estão assentadas exclusivamente no compromisso pessoal entre os envolvidos e no controle social estabelecido pelos próprios participantes do mercado (reputação). Assim, fazer parte de redes de troca recíprocas e estar bem posicionado nos circuitos por onde transitam as informações são pré-condições para o sucesso no mundo das finanças.

\section{Instituições de crédito e os grupos de baixa renda}

Entre os objetivos de outra pesquisa esteve o de explorar questões relativas às práticas, saberes e valores envolvidos nas relações entre as instituições que oferecem crédito pessoal e a população de baixa renda, que recentemente passou a ser vista como clientela desejável pelos agentes desse mercado. Buscamos compreender como os grupos sociais que estão recentemente sendo incorporados ao mercado de serviços financeiros (como resultado de políticas públicas ou através da ação das instituições financeiras que nele concorrem) vivenciam esse processo, isto é, como eles incorporam esses novos recursos e instrumentos em seu universo simbólico e em suas práticas cotidianas; como esses recursos e conhecimentos competem e são combinados com práticas e conhecimentos de caráter econômico e financeiro que já faziam parte da vida dessas populações (formas tradicionais de crediário oferecidas pelo comércio, carnês, cheques pré-datados, penhor, caderno de compras, crédito informal, formas tradicionais de poupança, redes de reciprocidade familiar, de vizinhança, etc.).

Um dos estudos desenvolvidos no âmbito desse projeto, foi a pesquisa de Luara Candido (2007), que enfocou o chamado crédito consignado, uma modalidade de crédito pessoal que é oferecido por bancos e financeiras e pelo qual são cobrados juros mais baixos que os do mercado, em razão das prestações serem descontadas diretamente junto à fonte de renda do credor. A oferta dessa modalidade de crédito foi liberada pelo governo há poucos anos, com o objetivo de permitir que aposentados, pensionistas 
e funcionários públicos obtivessem recursos pagando juros reduzidos porque avalizados pelo próprio Estado.

O estudo em questão, que enfocou especificamente a categoria dos aposentados, demonstrou que, embora as instituições levem em conta as condições financeiras individuais de seus clientes para avaliarem sua capacidade de endividamento, o mecanismo do crédito consignado é acionado para responder a necessidades de diversos membros do grupo familiar. $\mathrm{O}$ fato desses aposentados (em geral idosos), não raro os únicos membros das famílias a terem renda fixa, disporem de acesso privilegiado ao crédito resulta, em muitos casos, no aumento de seu poder no espaço doméstico. Em muitos outros, tem como efeito a diminuição de sua autonomia, em função do alto grau de endividamento que consome a sua renda no pagamento de empréstimos que foram assumidos como obrigações incontornáveis porque avalizadoras de seu desempenho no papel familiar de pai, mãe, avós, etc.

Outro mecanismo de crédito abordado em pesquisa vinculada ao mesmo projeto foi o penhor, um instrumento de crédito tradicional que continua muito utilizado em função dos baixos custos do crédito concedido (VICENTE, 2007; MÜLLER \& VICENTE, 2007). $\mathrm{O}$ uso de jóias e outros objetos de ouro como garantia para essa modalidade de empréstimo faz com que o funcionamento do penhor esteja diretamente vinculado à dinâmica do mercado dessa matéria prima, isto é, ao comportamento de uma commodity negociada através de bolsas e cujas cotações seguem dinâmicas globalizadas. O funcionamento do penhor também está vinculado ao mercado de jóias, cujo comportamento é ditado pelo sistema mundializado da moda, que estabelece os padrões de design e das técnicas de confecção, que hierarquiza as grifes, promove a reprodução dos modelos, etc. Esse mercado também engloba os circuitos regionais e locais de vendas de jóias, que reproduzem em diversas versões os modelos propostos pelos grandes joalheiros. Engloba, ainda, os mercados informais e/ou ilegais de jóias, mantido por vendedores ambulantes que circulam através de redes de clientes cujos vínculos pessoais ou profissionais avalizam a confiança que ele pode depositar no cliente quando oferece modalidades informais e personalizadas de crediário para a compra de seus produtos. Por fim, o penhor está 
vinculado aos mercados ilegais de ouro e pedras preciosas (extração clandestina, sonegação, contrabando, etc.), e também ao mercado do chamado "ouro usado" cuja compra é anunciada por pregões nos centros das grandes cidades.

Mas essa modalidade de crédito que se encontra articulada com mercados diversos só se mantém em funcionamento porque calcada em práticas cujos sentidos se definem no âmbito de relações sociais que se situam, em geral, no plano da intimidade, como as classificaria Zelizer (2005): relações familiares, afetivas, amorosas, relações pautadas por códigos sociais de gênero, de geração, etc. Isso porque as principais razões para que as pessoas comprem, ofertem usem e entesourem jóias é a de comunicar e festejar a passagem das diferentes etapas do ciclo da vida (nascimento, batizado, 15 anos), as mudanças de status social (formatura, noivado, casamento); de expressar o valor atribuído às relações afetivas e amorosas (namorados ofertam jóias às namoradas; maridos oferecem jóias às esposas, pais ofertam jóias às filhas, etc.).

Além disso, as jóias não são necessariamente bens de natureza individual. Apesar das mulheres serem as suas principais depositárias e usuárias (mais de $80 \%$ das operações de penhor são feitas por mulheres), como patrimônio, as jóias podem estar submetida às necessidades e ao controle do grupo familiar, que define quem pode e quando pode vendê-las ou penhorá-las, que define, também, quem tem o direito à sua herança (em geral, as jóias consideradas "de família" são transferidas de geração somente através das mulheres que possuem laços de consanguiinidade).

Assim, os estudos citados demonstram que a vida das instituições financeiras não está separada de outras dimensões da vida social e, também, que as lógicas que ordenam o funcionamento dessas instituições não são totalmente distintas das que pautam outras relações e práticas sociais. A seguir, continuaremos a desenvolver a problemática proposta, não mais na perspectiva das instituições financeiras, mas a partir do ponto de vista de quem acessa os mecanismos financeiros por elas oferecidos. Para isso, nos apoiaremos na história de vida de uma informante cuja trajetória traz elementos que nos ajudam a incluir na análise a 
"Então, eu fui à luta!": repensando as representações e práticas econômicas de grupos populares a partir de uma trajetória de ascensão social

possibilidade de pensar as questões até aqui colocadas em termos de dinâmicas, arranjos e combinações.

\section{Uma trajetória de ascensão social}

A trajetória de Vânia é exemplar em relação a um segmento social cuja mobilidade modificou o perfil das estatísticas sócioeconômicas do Brasil nas últimas duas décadas. Ela pode ser incluída na categoria que vem sendo denominada de "nova classe média" brasileira, isto é, segmento social formado por famílias que têm renda entre R\$1.064 e R\$4.591 mensais, conforme a estratificação proposta pela pesquisa da FGV (Neri, 2008). O rápido crescimento desse segmento (22,8\% entre abril de 2004 e abril de 2008), que fez com que ele englobasse atualmente $51,89 \%$ da população brasileira economicamente ativa, vem sendo atribuído a fatores como a elevação dos rendimentos e o aumento do acesso ao crédito para o consumo por parte de grupos situados nas classes de mais baixa renda (classes D e E).

Vânia tem 46 anos e é chefe de família. Sua principal fonte de renda é uma atividade exercida no do setor de serviços, mais especificamente, no ramo da estética pessoal. Vânia estudou até o ensino médio (8 anos de escolaridade), começou a trabalhar quanto criança, foi mãe pela primeira vez ainda na adolescência, mas teve apenas dois filhos, que já estão adultos, e um neto. Recentemente Vânia passou a viver junto com um novo companheiro. Ele tem o ensino básico, já foi padeiro e atualmente exerce a função de torneiro mecânico numa indústria da região onde moram.

Hoje Vânia tem duas casas que ela construiu no mesmo terreno: uma de madeira, que foi cedida ao seu filho, e uma de alvenaria, onde ela mora com o companheiro. Essa última é de construção recente, está equipada com geladeira, TV, aparelho de som, DVD, maquina de lavar roupa. Vânia adquiriu um computador para dar a seu filho e planeja comprar um carro em breve. Ela tem conta bancária, conta poupança, aplica seu dinheiro em um fundo de investimentos e tem cartão de crédito internacional. Também adquiriu o cartão de uma loja de material de construção e de móveis, onde ela comprou o que necessitava para construir e mobiliar sua nova casa. 
O lar de Vânia abriga dois cachorros: um para guarda (da raça pit bull) e outro que é tratado como habitante da casa (cadelinha da raça poodle), sendo levado todos os finais de semanas a um pet shop para banho e tosa. A casa conta com o serviço de uma faxineira a cada quinze dias.

A trajetória de ascensão experimentada por Vânia é produto de processos de natureza tanto social, quanto individual. Tentar isolar e avaliar cada um desses fatores é uma tarefa difícil. O que faz essa trajetória interessante em termos das questões aqui colocadas está no fato dela ser especialmente bem sucedida em termos econômicos e, ainda, que esse sucesso resulta de uma especial capacidade de organização e planejamento.

Os aspectos mais significativos presentes na narrativa de Vânia são as formas pelas quais ela compreende e organiza sua vida econômica e como ela concebe e avalia seu desempenho frente aos demais membros de seu grupo familiar de origem. Esses aspectos serão alvo da análise desenvolvida a seguir. Antes, porém, será apresentado um resumo da trajetória dessa informante, que nos permite apreender os processos de mais longa duração em que ela está inserida e, também, perceber como esses processos foram vivenciados e compreendidos por sua protagonista.

\section{Idas e vindas}

Vânia tem 46 anos. Ela nasceu no estado do Espírito Santo. Foi a última dos quatro filhos que a sua mãe teve em seu primeiro relacionamento. Todos os quatro foram "dados" para serem criados por outras pessoas (Vânia afirma ter uma irmã por parte de mãe e vários irmãos por parte de pai, que ela nunca conheceu). Quando pequena, conta, ela também foi "dada" para um casal que, conforme lembra, era muito pobre e vivia em condições muito precárias. Mas quando sua mãe resolveu mudar-se de cidade, indo atrás dos parentes que já haviam migrado, sua avó não aceitou receber a filha em sua casa sem que a mesma trouxesse a neta junto com ela. Então, com aproximadamente cinco anos, Vânia voltou a viver com a mãe, que foi morar de favor em uma chácara que ficava perto de um matadouro, na zona rural de uma cidade do interior do estado 
"Então, eu fui à luta!": repensando as representações e práticas econômicas de grupos populares a partir de uma trajetória de ascensão social

de São Paulo. Lá, a mãe de Vânia arrumou trabalho como faxineira e, mais tarde, como ajudante em um restaurante. Em São Paulo ela teve mais dois filhos de um novo relacionamento.

Vânia lembra que, enquanto a mãe trabalhava, ela cuidava da casa e de seus dois irmãos pequenos: buscava água, capinava, lavava roupa, passava roupa com ferro à brasa, pois não havia luz elétrica em sua casa. Também lavava fraldas para a família que era dona do terreno onde moravam, assim, ganhava alguns trocados para comprar as decalques de que gostava. Eventualmente, também ganhava algum dinheiro fazendo limpeza num pequeno mercado que ficava próximo à sua casa na volta da escola. Vânia rememora esse período da vida como sendo de muitas dificuldades e pobreza. Conta que eles não tinham dinheiro, não comiam bem (escondidas, as crianças pegavam ovos no quintal da chácara para sugá-los como se tivessem sido comidos por animais silvestres), caminhavam muito para irem à escola, pois não havia ônibus na região, e as roupas que usavam eram todas doadas. Vânia também conta que, de vez em quando, passava uma temporada na cidade, na casa da irmã de sua mãe, onde convivia com as primas. Com essa família, ela frequientou a igreja adventista, mas, segundo Vânia, "crente mesmo" era apenas o marido de sua tia, que deixara de beber ao se converter a essa religião. Na família de Vânia eram todos católicos, mas não iam à missa.

Vânia estudou até o final do ginásio. Ela afirma que desejava ser policial militar, mas não pode nem continuar a estudar porque engravidou de um namorado quando tinha 16 anos. Então, casouse, teve uma filha e foi morar com os parentes do marido, que era pedreiro. Vânia relata que a convivência com essa família foi difícil porque eram 13 pessoas morando na mesma casa e porque o único dinheiro certo que entrava no orçamento doméstico era o dela. Cansada de não ter autonomia, ela convenceu o marido a mudarem para uma outra casa. Mesmo assim, a relação não se manteve por muito mais tempo pois, segundo Vânia, o marido não ganhava muito dinheiro, era preguiçoso e gostava de bater em mulher.

Depois da separação, Vânia não conseguiu ninguém para cuidar da filha enquanto ela trabalhava. Então, entregou a menina para o pai, para ser cuidada pela avó paterna. Algum tempo depois, quando se casou novamente, Vânia foi buscar a filha para viver com 
ela. Na época, a menina já estava com cinco anos e não se adaptou mais com a mãe. Acabou sendo devolvida para a família do pai.

O segundo marido de Vânia era torneiro mecânico. "Ele tinha um pensamento parecido com o meu”, "queria futuro", diz ela. Quando se casaram, os dois trabalhavam e ela administrava o dinheiro da casa. Pagava as despesas do mês e guardava o que sobrava no banco. Tiveram um filho. Então, ele resolveu voltar para a sua cidade natal, no interior de Pernambuco. Sendo o único homem entre 18 filhos, ele achava que era sua obrigação estar lá para ajudar a família que se encontrava em um momento difícil (duas irmãs tinham morrido recentemente). Mudaram-se. Ele usou as economias do casal para comprar máquinas de fazer blocos de cimento e montou uma fábrica. O negócio deu certo. Com o dinheiro que ganhou, ele comprou dois açougues, abriu um pequeno restaurante e Vânia montou um salão de beleza. Ela conta que os dois trabalhavam muito e chegaram a ter 30 funcionários. Compraram chácara, terrenos, e iniciaram a construção de uma casa que, segundo Vânia, parecia uma mansão.

Tudo foi bem, conta ela, até que a empresa de seu marido foi assaltada. Roubaram-lhe todas as máquinas. Depois disso, o marido de Vânia remontou a fábrica, mas, segundo ela, "se desgostou" e vendeu-a logo em seguida. A partir daí, "ele perdeu as duas cabeças", como ela diz, começou a "arrumar mulheres". Quando Vânia resolveu se separar, descobriu que os bens do casal estavam todos registrados em nome do sogro. Ela recebeu apenas um carro velho e a casa que estava inacabada. Conseguiu vender o carro, trocar a casa em construção por outra menor, porém pronta, que acabou também conseguindo vender. Colocou o dinheiro da casa no banco, prometendo a si mesma guardá-lo com o objetivo exclusivo de comprar uma nova casa para si.

Vânia deixou seu filho, então com 12 anos, com o marido, em Pernambuco, e voltou sozinha para o interior de São Paulo, onde foi acolhida por uma tia que morava com o marido numa casa de dois cômodos. Logo que chegou, arrumou um emprego de governanta na casa do prefeito da cidade e, nos finais de semana, trabalhava como manicure e pedicure, atividades para as quais ela acha que tem um dom especial ("nasceu para isso"). Durante esse período, 
fez um curso de computação e frequientou cursos e congressos para se especializar em podologia.

Alguns meses mais tarde, Vânia largou o emprego de governanta e foi trabalhar em tempo integral como podóloga, num salão situado no município de Santo André (grande São Paulo). De segunda à sexta-feira, ela dormia no emprego para não precisar gastar em transporte para voltar para a casa da tia. Assim foi juntando dinheiro e, menos de um ano depois de ter chegado a São Paulo, alugou uma casa e foi a Pernambuco buscar o filho. Junto com ele, trouxe uma ex-cunhada que se dispôs a cuidar do menino enquanto ela trabalhava. Porém, algum tempo depois, a cunhada resolveu ir embora e Vânia achou melhor que o filho voltasse com ela para a casa do pai pois não teria como cuidá-lo sozinha.

Aproximadamente dois anos depois, a passeio, Vânia viajou a Porto Alegre na companhia de um namorado que tinha família morando nessa cidade. Encantou-se com o lugar e resolveu mudar-se. Procurou e encontrou trabalho como podóloga muito rapidamente, através da consulta a anúncios de jornal. A relação com o namorado acabou logo em seguida, mas ela resolveu mudar-se para a cidade assim mesmo. Alugou uma casa, mandou trazer os móveis de São Paulo e, assim que se viu instalada, trouxe o filho para morar com ela. Ele já estava com 15 anos.

Há oito anos em Porto Alegre, Vânia trabalha como podóloga em um salão de beleza que funciona dentro de um shopping situado na região central da cidade. Ela conta que, durante cinco anos, trabalhou durante 12 horas por dia, de segunda a segunda. Hoje, "só" trabalha das $10 \mathrm{~h}$ às $20 \mathrm{~h} 30 \mathrm{~min}$ ou $21 \mathrm{~h}$., e não trabalha mais aos domingos. No salão, ela tem um tratamento diferenciado em relação às outras profissionais, pois seu atendimento é considerado qualificado. Tem uma sala exclusiva para atender seus clientes, define seus próprios horários e paga um valor fixo ao proprietário, e não uma parcela de seus ganhos, como fazem os outros profissionais, que chegam a ter mais de $50 \%$ da renda de seu trabalho descontado pelo dono salão.

Vânia mora na região metropolitana de Porto Alegre, num bairro operário, rodeado por indústrias. Há alguns anos, ela comprou o terreno e construiu uma casa de madeira. Recentemente, construiu 
outra casa no mesmo terreno, desta vez de alvenaria. Para essa casa, Vânia comprou móveis novos e organizou uma festa de inauguração, para qual convidou colegas, amigas e clientes que, por sugestão sua, levaram presentes para o enxoval da casa nova. Vânia mudou-se sozinha e deixou a casa antiga para o filho, que hoje tem 23 anos, é solteiro, trabalha, mas ainda depende economicamente da mãe.

Vânia é uma mulher bonita, tem o porte elegante e gosta de se arrumar. Para manter a forma, faz caminhadas diárias nas ruas do bairro onde mora. De vez em quando, passa um final de semana na praia com amigos ou viaja a São Paulo para visitar os parentes. Sua atividade de lazer preferida é dançar. Com as amigas, ela é assídua frequientadora dos bailes que acontecem regularmente em clubes tradicionais da cidade (em geral nas quartas-feiras e domingos, entre $18 \mathrm{~h}$ e $24 \mathrm{~h}$.). Vânia conta que vai aos bailes para dançar. Vez por outra, arruma uma "paquera", mas afirma que nunca começa a namorar uma pessoa no mesmo baile em que a conheceu. Já teve alguns namorados que conheceu dançando e explica que alguns desses relacionamentos não progrediram justamente porque, depois de algum tempo, os namorados não queriam mais acompanhá-la nos bailes e não gostavam que ela os frequientassem sozinha (o que ela não deixava de fazer).

Mais de dez anos depois de se separar de seu segundo marido, há poucos meses, Vânia voltou a viver acompanhada. Ela se diz apaixonada, anuncia que vai ficar noiva e que eles vão casar no mês de maio do ano que vem. O noivo, que tem 32 anos, é separado e tem dois filhos pequenos que moram com os avós no interior do estado. Embora os dois morassem no mesmo bairro e ele costumasse jogar futebol com o filho de Vânia, só se conheceram recentemente num baile. Além de considerá-lo uma pessoa séria e trabalhadora (ele tem casa própria, já foi dono de uma padaria e agora trabalha como torneiro mecânico numa fábrica que fica no bairro onde moram), o que parece deixá-la mais encantada com essa nova relação é o fato do namorado não beber e gostar de dançar tanto quanto ela gosta.

Vânia diz que nunca foi uma pessoa religiosa, mas há alguns anos, quando estava construindo sua primeira casa (de madeira), teve muitos problemas: a casa não ficou como ela queria, o constru- 
tor roubou material, houve brigas, ameaças e até a necessidade de intervenção da polícia. Vânia estava "sufocada", então uma cliente sua contou que iria dar um curso de Reiki 3 e a convidou para se inscrever. Vânia tirou uma folga do trabalho, fez o curso e se sentiu tão bem que resolveu se preparar para ser uma praticante dessa técnica terapêutica. Ela faz parte de um grupo com o qual se reúne todo o ano para aperfeiçoar-se.

Em função da aproximação com o universo do esoterismo, Vânia entrou em contato com o que ela chama de "filosofia dos sete raios". A partir daí, começou a comprar livros e a estudar a respeito e virou adepta do que ela chama de "pensamento positivo", mais especificamente, do "poderoso" Saint Germain, "mestre ascencionado" que rege os raios de luz da cor violeta ou lilás. Hoje, Vânia tem a vida impregnada por essa crença. Na parede de sua sala de trabalho tem uma imagem de Saint Germain, ladeado por dois arcanjos. A fachada e várias paredes internas de sua nova casa são da cor lilás. Todos os sábados, dia dos "diretores da luz violeta", Vânia realiza em sua casa uma sessão de meditação e de Reiki que conta com a participação de seu noivo e para a qual ela convida amigos, vizinhos e clientes. A cerimônia que está planejando para seu casamento no próximo ano deverá ter uma ambientação baseada na filosofia dos sete raios: será no quintal de sua casa, que estará iluminado com tochas. Ela estará com um vestido de noiva lilás e o noivo usará uma gravata violeta. A música, que já foi escolhida pelo casal, tem inspiração esotérica.

\section{Economia doméstica}

A fala de Vânia parece reproduzir o conteúdo de um manual de economia doméstica. Além do controle estrito sobre os gastos, Vânia conhece e pratica várias formas de economizar nas tarefas domésticas.

Afirma ter uma dívida mensal de 450 reais. Além disso, gasta em torno de $\mathrm{R} \$ 1.000,00$ com as contas de água, energia, e na com-

2 Reiki é uma forma de terapia exercida através da imposição de mãos, com o objetivo de equilibrar as energias dos indivíduos, curar e evitar doenças. 
pra de comida para todo o mês. Segundo ela, esses valores estão comprometidos, são "sagrados". Quando vai ao supermercado, Vânia faz compras para todo o mês. Antes de sair de casa, prevê o que vai precisar nos próximos 30 dias, calcula o quanto vai custar e leva apenas o valor exato, em dinheiro. Compra apenas frutas e verduras da estação. Se achar produtos mais baratos, troca de marcas. Se economizar em relação aos gastos calculados, a compra pode render mais do que o planejado.

Em casa, Vânia controla muito o consumo dos produtos, o que acontecia mesmo quando morava com o filho. Comida, por exemplo, nunca vai fora. Só cozinha e serve o que vai comer. Vânia conhece técnicas para fazer render duplamente o detergente que compra (segundo ela, demasiadamente concentrado), dividindo o conteúdo do frasco em dois recipientes e completando-os com água. A água que sai da máquina de lavar quando as roupas são enxaguadas, Vânia usa para lavar a lavanderia, o banheiro e os tapetes da casa. As luzes da casa só ficam acesas nas peças onde as pessoas estão. A televisão só permanece ligada enquanto alguém estiver assistindo. Quando sai de casa, ela desliga todos "pontinhos vermelhos" (stand by) dos aparelhos. Quando recebe as contas de energia ou de água, Vânia as compara com contas anteriores. Se gastos forem maiores do que o de costume, procura identificar a causa e ver onde pode reduzir.

Vânia afirma ter todas as informações e fazer todos os cálculos de cabeça. Também não usa cheques. Acha-os muito perigosos porque facilitam a perda de controle dos gastos. O cartão de crédito ela usa apenas para comprar material de trabalho (esmaltes, produtos químicos), parcelando o pagamento no máximo em até três vezes para não acrescentar juros ao custo. Para manter controle sobre os gastos com o cartão, ela solicitou ao banco um limite que considera baixo (600 reais), o qual afirma nunca ter atingido.

Apesar da tentação cotidiana que sofre por trabalhar no interior de um shopping, Vânia afirma nunca se descontrolar. Sua única "tara", confessa, são os sapatos. Mesmo assim, ela só os compra quando consegue pagá-los à vista e com desconto no preço. Ou, então, quando consegue convencer a dona ou atendente da loja (provavelmente clientes suas) a guardar o calçado desejado até a próxima promoção, quando Vânia poderá comprá-lo mais barato. 
"Então, eu fui à luta!": repensando as representações e práticas econômicas de grupos populares a partir de uma trajetória de ascensão social

\section{Planejamento e poupança}

A gente tem que planejar. E o planejar não é só falar. É agir, e agir é guardar o dinheiro pra nunca ficar correndo atrás depois. Você sabe que as pessoas escutam a situação, o que você está passando, mas ninguém estende a mão com o dinheiro pra te dar. Então, você tem que ter o seu próprio dinheiro pra resolver a sua situação. $O$ que você acha?

Vânia diz que sempre guardou e investiu seu dinheiro em poupança. Mesmo enquanto esteve casada e vivia em Pernambuco trabalhando em seu salão de beleza e no restaurante de seu marido, uma das formas que ela encontrou para manter o valor do dinheiro frente aos altos índices de inflação foi estocar latas de óleo de cozinha. Cada vez que tinha um folga no orçamento, comprava e estocava caixas com latas de óleo. Quando o chamado plano real praticamente acabou com a inflação (1994), ela vendeu seu estoque de óleo para pessoas conhecidas, obtendo, segundo afirma, um bom lucro. Desse investimento resultou a reserva financeira que lhe garantiu autonomia quando se separou do marido e voltou para São Paulo, já que, na separação, recebeu poucos bens do patrimônio do casal.

Na narrativa de Vânia, poupar é um tema recorrente:

mas deixa eu explicar: uma vez por mês eu faço uma vistoria no dinheiro que eu guardei. Se tiver mais de $\mathrm{R} \$ 1.000,00$ ou $\mathrm{R} \$ 2.000,00$, a partir deste valor eu deposito... Eu fiz um fundo de investimento que tem que ser a partir de $\mathrm{R} \$ 500,00, \mathrm{R} \$ 1.000,00$. Conforme eu tenho, faço um depósito para essa conta e guardo o dinheiro lá, que é para segurar. Por isso que eu cheguei fazer a minha casa, porque fui guardando, guardando dessa forma. E quando eu fiz, tinha quase $\mathrm{R} \$ 50$ mil guardados. E é assim que eu faço, e continuo fazendo.

Quando busca explicar como consegue manter essa prática, ela recorre ao uso de noções que possuem referentes muito variados. Uma dessas noções é a de dízimo, numa explicita referência às práticas religiosas pentecostais. Nesse caso, a poupança é vista como um compromisso e comparável a uma demonstração de fé:

todo o dinheiro que você ganhar, nas suas mãos, é você conseguir dar $10 \%$ para você mesmo. É como se fosse o dízimo da Igreja. As 
pessoas não dão o dízimo para a Igreja Universal? Então você separa o seu dízimo todo. .... Vamos supor que você ganha R\$ 200 reais por mês. Como eu trabalho por semana, vamos supor que eu tiro R\$ 700 reais. De cada R\$ 100 reais, eu tiro $20 \%$.

A idéia de compromisso também aparece na noção de dívida com o banco:

Vamos supor na primeira semana tenho que pagar água. Então eu tiro da água. Aquele dinheiro eu não vou usar mais. Então o que eu faço? Abro uma poupança e daí eu faço uma dívida com o banco. Tem que ter dívida. Fora daquilo que eu tirei os $10 \%, 20 \%$ conforme for esse ai eu guardo em casa.

Quando pretende viajar, por exemplo, Vânia já diminui os gastos naquele mês, corta a compra de "banalidades" (roupas, bijuterias). Só viaja se já tiver acumulado o dinheiro necessário para isso. Vânia já foi associada a um plano de saúde, mas desistiu porque concluiu que não valia a pena. Avaliou estar perdendo dinheiro, pois pagava a mensalidade e ainda tinha que pagar as consultas médicas quando precisava. Então, resolveu que iria "fazer uma dívida com o banco", isto é, passaria a separar o valor que pagava para o plano $(\mathrm{R} \$ 150,00)$ e aplicá-lo todos os meses numa conta poupança. Esse dinheiro, segundo ela, só será movimentado para cobrir gastos com a sua saúde.

Vânia afirma ser dessa forma que, em quatro anos de trabalho duro, conseguiu juntar dinheiro para quitar o terreno e construir sua nova casa sem ter que fazer empréstimos. Diz que ainda tem dinheiro guardado e que pretende usá-lo na compra de um carro.

\section{Compromisso, heranças e rompimentos}

A vivência de precariedade e pobreza na infância é, segundo Vânia, o que fez com que ela buscasse mudar de vida, sendo essa, também, a razão de ter aprendido a lidar com dinheiro. Conforme conta, sua mãe era guerreira, trabalhadora, mas teve uma vida muito dura e acabou amarga, não soube usufruir. $O$ pouco que conseguiu juntar perdeu por ter emprestado para uma amiga que estava precisando. A amiga nunca devolveu o dinheiro e, quando a 
mãe envelheceu e ficou cega em razão de um glaucoma, não tinha mais nenhum recurso (hoje tem 73 anos).

Vânia começou a trabalhar fora de casa ainda quando criança (lavando fraldas, capinando, varrendo num mercado perto de sua casa) porque desejava comprar doces e decalques. Certa vez, o marido de sua tia aceitou financiar-lhe a compra de uma calça jeans. Ela pagaria a dívida em parcelas. Quando Vânia atrasou um dos pagamentos, o tio confiscou-lhe a roupa e nunca mais a devolveu, tampouco as prestações que ela já lhe havia pago. Esses fatos são emblemáticos na narrativa de Vânia. Ela os apresenta como justificativa para buscar nunca mais depender economicamente de ninguém, não emprestar dinheiro nem fazer dívidas que não possa pagar.

Como consegue guardar dinheiro, diversas pessoas lhe pedem emprestado, mas, segundo conta, ela aprendeu a negar porque sabe que quando precisar do dinheiro de volta, quem pediu não terá como devolver. Então, ela perderá o dinheiro e a amizade. Isso não significa que Vânia se sinta descomprometida com outras pessoas ou que não compartilhe a idéia de que parentes devam socorrer-se mutuamente. Pelo contrário, em sua narrativa são muitos os episódios que demonstram o quanto ela se sente responsável por vizinhos, colegas e familiares. Embora afirme estar "cansada de ajudar certas pessoas que abusaram de seu esforço", ela parece estar sempre buscando uma forma de exercitar essa responsabilidade:

Tenho uma vizinha, que mora do meu lado, que o marido é uma pessoa que só fuma droga. Tem três crianças pequenas e estão até sem luz. Como eu não quero dar luz e essas coisas, ontem fui no supermercado, de vez em quando eu faço isso, compro bolacha, danoninho e dou para eles. Dou com o maior amor e carinho, os coitadinhos não pediram para vim no mundo e as criaturinhas estão sofrendo muito, e eu faço isso. E olha que ela foi bem ignorante comigo uma vez, mas eu não olhei a ignorância dela, eu olhei pelas crianças. Eu acho que as pessoas na luta são ignorantes e as crianças nem sabem por que estão passando por aquela situação. E quando eles me enxergam dizem: - Tia Vânia "gute". E eu respondo: - A tia Vânia hoje não tem, mas vou providenciar. Na outra semana eu dou novamente, entrego um pacotão de salgadinho e ficam todos felizes. E assim nós vamos fazendo as coisas. É dar de coração, dar sem sentir retorno. Eu não dou para 
receber o retorno. Dou porque acho que eles estão precisando e eu dou. Não dou dinheiro porque acho que dinheiro você não deve dar. Você deve dar o pão e matar a fome da criança, e até colocar uma roupa, mas dinheiro não deve dar.

Chegava no fim do mês, eu tirava $R \$ 50,00$ para mamãe, $R \$ 25,00$ para a tia $D$, mais $R \$ 25,00$ não sei para quem, mais $R \$ 50,00$ pro fulano, mais R\$ 25,00... No fim, saiam R\$ 300,00 do meu dinheiro todo o mês para ajudar eles e eu vi que eles ficavam imóveis. - A coisa besta da Vânia vai dar... E um dia eu disse: - Não Vânia, não é assim que você ajuda. Eles vão ter que sofrer para apreender. E eu larguei de mão. Até a minha filha que ganhou neném, eu mandava roupa, mandava dinheiro, mas... - Espera ai! Ela é uma moça bonita, jovem e com saúde. Eu não mandei ela ter filho. $\mathrm{O}$ filho é dela e é ela que vai criar. Quando eu vou lá, eu pego o gurizinho, levo numa loja de roupa e pergunto: - O que tu quer? E ele diz: - Eu quero isso e isso. E dou a roupa. Dinheiro, não porque se eu fizer isso eles vão ficar esperando muito. E eu aprendi que não é isso e dessa maneira que eles vão me ganhar. São desunidos. Porque, se fossem uma família unida, não passavam...

Eu já ajudei muito essa minha tia, mas se fosse só para ajudá-la a ter as coisas, eu ajudaria mais. Eu até parei de ajudar numa época porque eu sempre mandava dinheiro, depositava, e quando ia lá... Às vezes, quando eu vou, eu prefiro ajudar pessoalmente. Eu vou no supermercado, compro alguma coisa que ela gosta e dou para ela. Saímos para fazer compras e digo: - Escolhe tia, que eu vou pagar. Ela escolhe e eu pago. Porque, na realidade, se eu mandar dinheiro para a minha tia e ajudar em outras coisas para ela, quem vai comer são os outros. A casa dela é sempre cheia. Tem dois netos e uma filha que vivem praticamente dentro da casa dela e ela não têm assim... mesmo seu eu der uma coisa para ela, ela não vai usufruir, quem vai usufruir são as pessoas. Então, é melhor eu dar pessoalmente o que ela gosta também. Mas é uma tia maravilhosa, gosto muito dela e faz tempo que eu não falo com ela. Mas em breve vou falar porque quando falo com ela, ela chora e eu tenho vontade de trazê-la para ficar comigo. Mas não no frio, senão a coitadinha vai morrer. Apesar de que lá em São Paulo esteja fazendo frio.

Nas falas de Vânia se encontra muito clara a idéia da existência valores e padrões de comportamentos que se reproduzem através da convivência familiar, e que impedem que os indivíduos modifiquem suas condições de vida: 
São umas pessoas muito devagar... Eu venho de uma família onde as pessoas são muito devagar. São pessoas descansadas, parece que nasceram e o tempo parou ali. Eles não procuram melhorar, são pessoas paradas, que não têm iniciativa... Passo dois anos sem vê-los (...) e eles estão sempre na mesma vida. É como tivesse um buraco e eles rodassem por volta daquele buraco. Aquilo me irrita quando eu vou, porque eu sou uma pessoa diferente, e digo: - 0 que vocês querem da vida? Saiam dessa vida! É a mesma história, o mesmo problema, não muda!

Desses padrões, nem a sua própria filha escapou, em razão, segundo Vânia, de sua convivência com a família do pai (primeiro marido de Vânia). É dessa forma que ela explica o fato da filha ser muito diferente dela, pois a moça já tem 28 anos, casou-se, teve um filho, vive mal, mas não se dispõe a trabalhar. "Ela acha que tem que ganhar tudo sem esforço" "ficou meio perdida", "não tem vontade de crescer", "não vê o horizonte lá na frente", assim a define Vânia.

Em relação ao filho, Vânia se coloca de outra forma. Até poucos meses atrás, ele morava com a mãe e usufruía do sustento da casa, que era promovido por ela. Agora que ele mora sozinho na antiga casa que ganhou de Vânia, ela diz que ele se sustenta por conta própria. Entretanto, também explica que planeja solicitar a separação das contas de água e de energia para que ele assuma as suas despesas sem que ela tenha que cobrar-lhe os valores a cada mês. Vânia aposta que seu próprio exemplo tenha um efeito pedagógico em relação ao filho, uma vez que, segundo ela, já teve efeitos em relação ao pai do rapaz (seu ex-marido):

Agora, o Marcos, acho que ele aprende porque o pai dele também, vendo eu fazendo essa função, ele entrou na minha. Até no tempo em que vivia junto com ele, nunca foi um homem endividado, essas coisas. Era um homem bem concentrado no que fazia. Se o Marcos puxou, não vai se endividar. Esses dias eu falei: - Marcos, porque você não comprou isso? Ele respondeu: - Mãe, eu estou fazendo e pagando as minhas compras. Então, senti que ele é parecido com a mãe dele. Esses dias ele falou: - Mãe, você tem um monte de sapato e eu só tenho um par. E eu falei: - Mas é porque eu posso e eu não estou devendo nenhum. Não vem colocar olho no meu sapato. Porque geralmente acontece isso: o que eu tenho que 
controlar mesmo é no sapato. E eu já estou conseguindo comprar sapato e sobrar dinheiro. Agora, o dia em que não sobrar, eu fico doente e tem que me internar.

Vânia afirma que divide as despesas equitativamente com o noivo que veio morar com ela. Como está segura de que essa nova relação é para a vida toda, ela resolveu que, mesmo antes da festa de casamento, os dois irão ao cartório fazer um registro formal de união estável. Ela também planeja que cada um deles fará um testamento, nomeando os filhos como herdeiros das suas respectivas casas. E para que ninguém corra o risco de ficar sem ter onde morar, Vânia está propondo que o casal abra uma poupança conjunta e façam depósitos regularmente até terem dinheiro suficiente para darem de entrada para a compra de apartamento cujo financiamento poderá ser pago através da sua locação a terceiros. O apartamento será a garantia de teto para o cônjuge que sobreviver ao outro. Ao ser perguntada sobre a fonte do dinheiro da poupança conjunta para a compra do apartamento, Vânia respondeu que uma delas serão as despesas que o casal não faz quando sai para dançar, pois, em qualquer baile, explicou-me, quem gosta de beber gasta em torno de 30 reais numa noite. Como os dois bebem apenas água, a cada baile que vão, têm mais ou menos essa quantia para colocar na poupança.

O noivo de Vânia ganha pouco porque iniciou a carreira de torneiro-mecânico muito recentemente. Além disso, ele tem que pagar pensão para os dois filhos pequenos. Para aumentar a sua renda, Vânia o incentivou a fazer valer suas habilidades de ex-padeiro. Ela mandou fazer um banner e o colocou na frente da casa, anunciando a venda, por encomenda, de doces e tortas. Saiu com ele e comprou-lhe um forno especial para assar pães e bolos, financiado em dez prestações mensais. Vânia explica que, com a venda das tortas, o noivo lhe pagará o crediário do forno que está em seu nome e, quando ele o tiver quitado, ela lhe dará um recibo para que ele saiba que o equipamento é seu (caso venham a se separar, ele poderá levá-lo embora).

Vânia parece entusiasmada com o novo projeto. Ela faz propaganda das tortas para as clientes do salão e se dispõe a carregar sacolas cheias de encomendas quando vai para o seu local de traba- 
lho. Já está pensando em comprar uma batedeira maior para que ele consiga produzir muitos panetones para a época do natal. $\mathrm{O}$ forno foi instalado na cozinha da casa em caráter provisório, pois ela já tem planos construir um "puxado" o fundo do terreno para sediar o novo empreendimento ("pequenas empresas, grandes negócios", fala ela, demonstrando satisfação). O novo espaço já está desenhado na sua imaginação (uma cozinha grande, com uma janela ampla, equipada com pia, armários, uma mesa para trabalho, um lugar para guardar os produtos e, em separado, um banheiro exclusivo). Vânia também já está fazendo os cálculos do custo da construção. Apesar disso, ela diz que não quer se envolver com o trabalho na cozinha, apenas ajudar o noivo a organizar o negócio.

\section{Eu sempre fui diferente...}

Embora reconheça ter usufruído do apoio familiar em momentos importantes da vida, Vânia atribui sua bem sucedida trajetória pessoal e econômica à sua capacidade de fugir ao padrão familiar. E essa capacidade é vista como uma característica individual. Sua fala é constantemente pontuada por expressões que aludem à sua "força pessoal", aos seus dons individuais ("nasci com o dom de manicure”, ou com o "dom para ser podóloga”), e às suas realizações pessoais ("eu sou minha própria pirâmide").

Não tinha ninguém para me orientar, aconteceu isso dentro de mim, uma explosão de conhecer o mundo e de saber como era foi por mim própria. Claro que eu tenho certeza que existe um anjo muito bom e maravilhoso dentro de mim que me encaminhou também. Eu gostaria de ter sido melhor, mas não posso me queixar.

As doutrinas esotéricas, que foram incorporadas à sua vida há poucos anos, forneceram a Vânia um quadro que lhe permite dar sentido e coerência a essa trajetória. Através do que ela chama de "pensamento positivo" ou de "mentalização", Vânia consegue explicar sua motivação para novos projetos e a sua persistência nos esforços para a sua realização. É assim que aconteceu explica o que aconteceu com o projeto de construção de sua casa nova: 
Quando eu comecei a fazer essa minha casa, eu pensei bastante porque eu tive uma decepção com a outra casa que eu fiz, por não ter experiência, talvez por não ter o pensamento tão positivo, tão certo, e deu tudo errado. Perdi muito dinheiro, teve confusão na minha casa e eu tive uma decepção tão grande que eu cheguei a passar um dia chorando, sem conseguir parar, uma coisa que eu nunca tive. ...E a partir daquele dia em que aconteceu tudo isso, eu me retive, eu comecei a colocar dinheiro no banco e comecei a memorizar (sic): Eu vou fazer uma casa e essa casa vai ser radiante, vai ser cheia de luz. Eu me apeguei a Saint Germain, e em tudo que eu toco eu coloco raios de luz de Saint Germain, que são raios de cor violeta, que é o pensamento positivo. Então, eu uso muito o pensamento positivo para atingir os meus objetivos. Eu pedi para Saint Germain que ele colocasse o pedreiro certo na minha porta e que ele ia tocar em mim qual era a pessoa certa. ... A Camila, que é a minha nora, ela perguntou se eu já tinha pedreiro e eu falei que não havia me interessado por ninguém, e ela disse que o irmão do namorado dela era pedreiro, uma pessoa honesta, trabalhadora, pessoa de responsabilidade e que vai fazer a casa do jeito que você pedir e não gasta o material mais do que deve. E eu disse que queria falar com ele. Quando eu olhei para o homem, era ele, e fechei com o homem. ...E todo o tempo que eu fechei com esse pedreiro, raios de luz sobre esse pedreiro, sobre o ajudante do pedreiro, o material, e toda a casa estava radiados de luz, que eu pedi. A casa saiu, foi levantada a casa e foram chegando outras coisas: janelas, portas... E não para por aí: vamos colocar os vidros... E não terminou por ai: eu queria colocar pisos, forros, tudo... A minha casa é toda baseada em Saint Germain. É toda cheia de luz e raios de luz que eu busco, que está sendo memorizada com raios de luz. Até a cor da minha casa vai ser lilás clara, com cor de violeta nos portões. Quem passar na frente da minha casa vai receber raios de luz. Ela já está radiando.

A crença nos poderes dos raios violeta de Saint Germain explica a grande capacidade que Vânia tem de superar os problemas e de atrair acontecimentos que ela considera positivos, inclusive no plano financeiro, como se pode perceber no diálogo reproduzido a seguir:

- Hoje mesmo eu passei por um problema: aquele telefone tocou e era do Banco do Brasil, avisando que havia sido remetido o cartão internacional e que eu havia sido escolhida.

- E o que você vai fazer o cartão internacional?

- Não sei. Vou lá porque me chamaram, 
"Então, eu fui à luta!": repensando as representações e práticas econômicas de grupos populares a partir de uma trajetória de ascensão social

- Você tem conta no Banco do Brasil?

- Tenho conta de banco e tudo. E falaram que eu fui escolhida para ter um cartão internacional. Que é difícil, mas que eu fui escolhida por ter conta há muitos anos e porque eu nunca havia tido problema no banco. E por esses motivos eu fui escolhida. São essas meditações que eu faço, acendo incensos e busco os raios de luz de Saint Germain. O que os sete raios da cor violeta têm me dado, assim...É fantástico que eu vou te contar. É uma coisa de arrepiar.

\section{Uma trajetória, muitas questões}

Com esse texto, buscou-se refletir sobre as fronteiras, que se presume existir, entre os princípios que regem os procedimentos dos agentes financeiros dominantes e as lógicas que orientam a vida econômico-financeira dos indivíduos pertencentes às camadas populares.

Na primeira parte, retomamos as idéias desenvolvidas em outros trabalhos, buscando mostrar que o funcionamento das instituições financeiras não está calcado em exclusivamente em uma ideologia de caráter individualista; que elas não estão submetidas de forma absoluta à lógica da maximização e que não atuam necessariamente com base no cálculo formal e abstrato.

Num segundo momento, buscamos relativizar a idéia de que as representações e práticas econômicas dos indivíduos que tem origem em grupos populares são necessariamente ou somente pautadas por princípios holistas, pela submissão a padrões e obrigações familiares tradicionais, baseados numa forte demarcação de papéis sociais de gênero e de geração, e que suas ações sejam baseadas exclusivamente numa lógica imediatista e no cálculo prático.

Embora a trajetória de Vânia apresente vários elementos (renda, padrão de consumo) que permitam classificá-la como pertencente à classe média, sua história familiar e suas vivências na infância (pobreza, doação de crianças, trabalho infantil, gravidez e casamento precoces, etc.) evidenciam claramente sua origem nas chamadas classes populares. E mesmo que a partir do segundo casamento ela tenha tido a experiências de diferentes graus de sucesso econômico, Vânia continua até hoje vivenciando uma realidade social que, em termos de moradia (mora num bairro operário), hábitos de lazer 
(frequientar bailes), ocupação profissional sua e do noivo (trabalho manual), pode ser definida como popular.

Essa trajetória é significativa, não apenas em razão de sua dinâmica ascensional, mas, sobretudo, pela capacidade que sua protagonista apresenta de administrar os processos em que se viu envolvida, tanto em termos pessoais quanto em termos econômicos. Pelos dados obtidos, não se pode dizer que essa dinâmica apoiou-se na existência de um projeto de vida pessoal. Pelo contrário, tudo leva a crer que a possibilidade de construção de um projeto foi o resultado de um percurso que se produziu a partir da tentativa de fuga dos contextos e situações iniciais de precariedade e limitações (econômicas, afetivas). Ao longo desse percurso é que foram sendo encontradas e criadas (nem sempre de forma voluntária) as condições que permitiram a elaboração de metas e objetivos pessoais.

Essas condições estão provavelmente ligadas à possibilidade de distanciamento de Vânia em relação aos papéis de gênero tradicional (mãe e filha), bem como das obrigações com a família de origem (irmãos, tios, primos), cujas necessidades poderiam colocar limites a extraordinária capacidade de trabalho e de administração econômica e financeira demonstradas por Vânia. Nesse sentido, com certeza, as mudanças que a levaram para longe da família em termos geográficos tiveram um papel fundamental.

A atividade profissional desenvolvida por Vânia também é um elemento importante para a compreensão de sua trajetória porque a coloca cotidianamente num contexto de mediação social (VELHO, 2001). Em seu trabalho, Vânia convive com pessoas (seus clientes) que, em sua maioria, têm padrão de renda, escolaridade e de consumo mais altos do que os seus. E essa convivência se dá sob a forma de atendimento pessoal e individualizado, o que permite a criação de intimidade e de laços duradouros. Essas relações constituem um canal de trocas em diversos âmbitos: econômico, afetivo, terapêutico, de informações, de serviços, e mesmo de ajuda e orientação espiritual, se assim pudermos classificar as práticas esotéricas.

Por fim, a adesão de Vânia a crenças e práticas esotéricas inseriu-a num registro ideológico e moral de caráter individualista que explica a diferenciação e o distanciamento que se estabeleceu 
entre ela e seu grupo familiar de origem e legitima a sua trajetória de ascensão, sendo, também, uma fonte de reconhecimento social em razão dos serviços terapêuticos e espirituais que ela oferta aos membros da família (noivo, sogros), aos amigos e clientes. Essas crenças fazem com que, em seu cotidiano, Vânia esteja em constante contato com o transcendente. Contato esse que se coloca em perfeita harmonia com a sua extraordinária capacidade de planejar, avaliar, contabilizar, administrar. Mais do que isso, ele é a condição para que essas capacidades tenham efeitos concretos, tanto em termos econômicos quanto em termos de satisfação pessoal.

A trajetória de Vânia coloca em xeque a possibilidade de se ver indivíduos oriundos de classe popular como portadores de representações homogêneas e imutáveis. Também demonstra que, assim como acontece no funcionamento normal das instituições financeiras, as lógicas que ordenam suas práticas podem ser muito variadas e diversamente combinadas. Isso não implica em negar a hipótese que fundamentou o problema inicial de nossa pesquisa, que é a da existência de diferentes sistemas de simbolização em uma sociedade de classes ou, conforme a formulação de Fonseca (2000, p. 211), a "hipótese da alteridade" inscrita no jogo da estratificação social, apenas que devermos refinar a leitura dessas diferenças e tentar compreendê-las em termos complexos e dinâmicos, como parece ser a sociedade brasileira.

Recebido em 30.7.2009

Aprovado em 16.9.2009

\section{Referências}

CANDIDO, L.F.de. Crédito sobre a ótica da terceira idade: significados da utilização do empréstimo pessoal para idosos. Porto Alegre, PUCRS, 2007 (TCC graduação em Ciências Sociais).

DUARTE, F.D. \& GOMES, E.C. Três famílias: identidade e trajetórias transgeracionais nas classes populares. Rio de Janeiro, Editora FGV, 2008.

DUFY, C. \& WEBER, F. L'ethnographie économique. Paris, La Découverte, 2007. 
FONSECA, C. Classe e recusa etnográfica. In: FONSECA, C. \& Brites J. Etnografias da participação. Santa Cruz do Sul, EDUSC, 2006.

. Família, fofoca e honra: etnografias de relações de gênero e violência em grupos populares. Porto Alegre, Editora UFRGS, 2000.

JARDIM, M.D.R. Negociando Fronteiras entre o Trabalho, a Mendicância e o Crime: uma etnografia sobre família e trabalho na Grande Porto Alegre. Dissertação de Mestrado, Porto Alegre, UFRGS, 1998.

KUMAR, A. (Coord.) Brasil: acesso a serviços financeiros. Rio de Janeiro, IPEA; Washinton, DC, Banco Mundial, 2004.

MATTOSO, C.L. Identidade, inserção social e acesso a serviços financeiros: um estudo na favela da Rocinha. Rio de Janeiro. Tese de doutorado (COPPEAD). Universidade Federal do Rio de Janeiro, 2005.

MÜLLER, L.H.A. Mercado Exemplar: um estudo antropológico sobre a bolsa de valores. Porto Alegre, Zouk, 2006.

MÜLLER, L.H.A. \& VICENTE, D.S. Vão-se os anéis: uma abordagem etnográfica do penhor. Anais $31^{\circ}$ Encontro Anual da ANPOCS, Caxambu, 2007.

NERI, M.C. (Coord.) A nova classe média. Rio de Janeiro, FGV/IBRE CPS, 2008.

SARTI, C.A. A família como espelho: um estudo sobre a moral dos pobres. São Paulo, Cortez, 2003.

VELHO, G. Biografia , trajetória e mediação. In: VELHO, G. \& KUSCHNIR, K. Mediação, Cultura e Política. Rio de Janeiro, Aeroplano, 2001.

VELHO, G. Projeto e metamorfose: antropologia das sociedades complexas. Rio de Janeiro, Zahar, 1994.

VICENTE, D.S. Vão-se os anéis, ficam os dedos? Uma abordagem etnográfica do penhor. Porto Alegre, PUCRS, 2007. (TCC graduação em Ciências Sociais).

WEBER, F. Práticas econômicas e formas ordinárias de cálculo. Mana, out. 2002, vol.8, n.2, p.151-182.

ZELIZER, V. Intimité et économie. Terrain, n.45, Paris, sept. 2005. (L'argent em famille). 
"Então, eu fui à luta!": repensando as representações e práticas

econômicas de grupos populares a partir de uma trajetória de ascensão social

Lúcia Helena Alves Müller

\begin{abstract}
"So I took up the struggle!" : rethinking economic representations and practices of popular groups through trajectories of social mobility
\end{abstract}

This text raises questions that emerged while developing research on the process, currently underway in Brazil, in which popular groups' attain increased access to financial services and mechanisms and the credit supply available to low income people has expanded. Using one informant's trajectory as our guiding thread, we will take a critical look at some of the original premises of our research and attempt to put together new research hypotheses. The latter are meant to relativize differences and take a more nuanced approach to the borders which we had initially supposed could be drawn around the logics that guide the economic and financial life of individuals of popular classes and the principles that reign actions of the agents who provide them with financial services.

Keywords: Economic Anthropology, Economic Sociology, credit and consumption, popular classes and economic practices, social mobility. 
